\title{
An exploration of the associations of pregnancy and perinatal features with cytokines and tryptophan/kynurenine metabolism in children with attention-deficit/hyperactivity disorder (ADHD)
}

\author{
Robert D. Oades
}

\author{
2011, ADHD Att. Def. Hyp. Disord., 3, 301-318 \\ This is the reformatted manuscript submitted - prior to publication in its final form at \\ (www.springerlink.com) DOI 10.1007/s12402-011-0062-2
}

Clinic for Child and Adolescent Psychiatry and Psychotherapy, University of Duisburg-Essen, 45147 Essen Germany. Email: robert.oades@uni-due.de

\begin{abstract}
:
Background: Intra-individual variability of the characteristics of children with attentiondeficit hyperactivity (ADHD) may reflect compromised glial energy supply in the synapse. We reported recently that while serum levels of a glial marker, the cytokine S100B, were not seriously altered, levels of other cytokines and tryptophan metabolites related to symptoms, attention and variability. Here we explore with a regression analysis whether levels of these substances were associated with features of the index pregnancy of potential aetiological significance.
\end{abstract}

Methods: Serum was taken from 35 children with DSM-IV ADHD (14 on medication) and 21 typically-developing controls to measure 8 cytokines (S100B, IL-2, IL-6, IL-10, IL-13, IL-16, TNF- $\alpha$ and IFN- - ) and 5 metabolites (Tryptophan, Kynurenine, Kynurenate [KA], 3-hydroxykynurenine [3HK], 5-hydroxyindole acetic acid [5-HIAA]). The mothers received a 124-item questionnaire on features surrounding the pregnancy.

\section{Results:}

1) For children with ADHD a shorter pregnancy and smaller birth weight was associated statistically with increased $3 \mathrm{HK}, \mathrm{IFN}-\gamma$ and, for obstetric problems with decreased TNF- $\alpha$ levels.

2) Maternal smoking related to decreasing kynurenine and increasing $3 \mathrm{HK}$ and $\mathrm{S} 100 \mathrm{~B}$ levels in ADHD children. Paternal smoking was associated with increased tryptophan in the controls and increased IL-6 levels in ADHD children.

3) The taking of supplements often related to decreasing TNF- $\alpha$, increasing IL-10 and lower 5-HIAA levels in the ADHD children. Less 5-HIAA but more tryptophan was associated with earlier and later life events, respectively.

4) Increased IL-16 and 5-HIAA levels in the ADHD group related to reports of poorer infant health. Unexpectedly, more child care (seafood and time-together) in ADHD than healthy families was implicated by lower tryptophan levels and an altered balance of proinflammatory cytokines. Across measures control families generally showed either nonsignificant associations or the opposite to those of the ADHD group.

Conclusions: In ADHD children more than controls, the balance of potentially toxic or protective kynurenine metabolites and of pro- over anti-inflammatory cytokines may reflect the perinatal experience associated with stress, but not with maternal illness. 


\section{Key words:}

ADHD; Birth; Cytokine; Kynurenine; Pregnancy; Tryptophan

\section{Abbreviations:}

ADHD, Attention-deficit/hyperactivity disorder; DSM-IV, Diagnostic and Statistical Manual of the American Psychiatric Association, $4^{\text {th }}$ edition; HI, hyperactive-impulsive; 5-HIAA, 5-hydroxy-indoleacetic acid; IA, inattentive; IL, Interleukin; IFN- $\gamma$, Interferon gamma; KA, kynurenic acid; 3HK, 3-hydroxy-kynurenine; NAD, Nicotinamide adenine dinucleotide; NFKB, Nuclear factor kappa-light-chain-enhancer of activated B cells; SES, Socio-economic scale; SD, Standard Deviation; TNF- $\alpha$, Tumour necrosis factor alpha;

\section{Acknowledgments:}

I am very grateful to Benno Schimmelmann, Maria Dauvermann, Victoria Kirchhoff, Adriana Banozic and Ellen Uslar for their help in running this study in Essen, and to Aye-Mu Myint, Markus Schwarz and Johana Zach for their role in organizing and running the biochemical analyses in Munich. We thank UCB Pharma GmbH for financial support.

\section{Competing interests:}

RDO declares that he has no conflicting interests. Some of these data were communicated at the $10^{\text {th }}$ Psychoimmunology Expert meeting at Ulm/Günzburg, 12-14 ${ }^{\text {th }}$ Nov. 2009 (Oades et al. 2009).

\section{Introduction}

A diagnosis in childhood of attentiondeficit and hyperactivity disorder (ADHD) is likely also to include impairments such as cognitive and behavioural impulsivity, poorly developed executive functions and comorbid internalizing and/or externalizing characteristics. Most prevalent is a clinical impairment of the combined type (around 5\%: Polanczyk et al. 2007). A potential endophenotype of the disorder is the variability of expression of these symptoms and of the responses on neuropsychological tests in the laboratory (Castellanos and Tannock 2002; Klein et al. 2006; Kuntsi et al. 2005; Uebel et al. 2010). Russell et al. (2006) proposed that an altered aspect of the metabolic activity of glia may underlies this variability. This report explores the potential relationships of some perinatal and pregnancy-related features to the development of possible molecular and inflammatory underpinnings of this explanation of variability in offspring who develop ADHD.

Russell and colleagues (2006) proposed that the intra-individual varia-bility of response may reflect an impaired supply of energy from glial cells to maintain the neuronal firing necessary to sustain responses (the lactate shuttle: Gallagher et al. 2009). We investigated recently whether a marker of the integrity of glial function was compromised (Oades et al. 2010a). Serum levels of the cytokine S100B, that is largely but not exclusively produced by astrocytes (Steiner et al. 2007), proved not unusual or tended to be decreased slightly in those with internalizing symptoms.

Our pilot study (Oades et al. 2010a, b) also looked at tryptophan/kynurenine metabolism that largely takes place in glia (Kiss et al. 2003) and some other cytokines that influence this metabolism (Myint et al. 2007). Kynurenine metabolites are of interest as they can have neuroprotective (kynurenic acid, KA) or potentially neurotoxic properties (3-hydroxy-kynurenine, $3 \mathrm{HK})$, as a glutamate antagonist and agonist respectively, with the predominant pathway modulated by the balance between pro- and anti-inflammatory cytokines (Myint et al. 2007). Allergies and related inflammatory conditions (e.g. atopic eczema) with a prevalence of up to $50 \%$ in children with ADHD underscore the interest in the cytokines contributing to such immunological reactions (Blank and Remschmidt 1994; Romanos et al. 2010). 
We described a modest increase of some cytokines in patients with ADHD (e.g. interferon- $\gamma$, IFN- $\gamma$ ) that normalised in a medicated group (Oades et al. 2010a). Increased levels of IFN- $\gamma$, IL-13 and IL-16 related respectively to increased reactiontime variability, inattention and hyperactivity. In addition, IL-16 levels correlated with reported allergy sensitivity. Although most tryptophan metabolites were not significantly related to symptoms, increased levels of tryptophan and its breakdown products were associated with continuous performance accuracy and reaction time (Oades et al. 2010b). However, lower levels of the potentially toxic $3 \mathrm{HK}$ in the ADHD than the healthy group were interpreted speculatively as consistent with developmentally delayed neural pruning processes (Bourgeois and Rakic 1993; Huttenlocher 1984).

Although some modest genetic associations for cytokines with ADHD have been reported (Lasky-Su et al. 2008) we concentrate in this report on exploring whether serum levels of tryptophan metabolites in the serotonin or kynurenine pathway or the cytokines that influence them were related to environmental events immediately before, during or just after the index pregnancy.

Human studies have shown that a wide variety of prenatal stressors (e.g. anxiety, partner relationship problems, natural disasters) increase the risk for a diverse range of adverse neurodevelopmental outcomes in the child ( $O^{\prime}$ Donnell et al. 2009). For example, Stöber et al. (2009) pointed out relationships between maternal infection, cytokine changes and the risk for schizophrenia in the offspring. King et al. (2010) review a large range of environmental experiences of the foetus and developing child that have been associated with the eventual diagnosis of psychosis and its biochemical concomitants. Animal models have elaborated details on how stress in utero may be reflected in the bases underlying later cognitive difficulties of the offspring (e.g. the expression of the SNAP-25 protein in the hippocampus: Fatemi et al. 1998). The present study is based on the premise that the biochemical bases underlying the cognitive and symptomatic characteristics of ADHD may likewise reflect some of the difficulties the mother experienced in the pregnancy and perinatally.

Numerous studies have reported that pre-/perinatal adverse environments and experience, (e.g. stress and deprivation), can not only delay the experiencedependent maturation of the CNS in the foetus and infant, but also induce permanent changes in prefrontal cortical wiring patterns and the metabolism underlying their function (Bock and Braun 2011; Boksa 2010). A potential mechanism was addressed by Hsaio and Patterson (2011) who pointed out that: maternal immune responses can alter placental endocrine factors that influence the nature of foetal development. Indeed, a range of mechanisms may mediate the maternal experience to the developing infant: for example the reduced size of the hippocampus and associated behavioural impairments in the infant that result from intrauterine growth restriction may reflect maternal corticosteroid hormone exposure, hypoxemia, and micronutrient deficiency (Lodygensky et al. 2008). In addition, McClelland et al. (2011) have described the epigenetic mediation of the long-lasting effects of early experience on learning and memory abilities.

Indeed, a number of features of the pregnancy have been claimed already to be associated with the later development of ADHD in the offspring. For example, maternal smoking (Gustafsson and Källen 2010), alcohol consumption and low birth weight may put a child at risk for developing ADHD (Das Banerjee et al. 2007; Knopik et al. 2005, 2009; contrast O'Callaghan et al. 1996). Mothers who 
experience and produce high levels of certain cytokines are more likely to have infants who produce high levels of the same cytokines (Djuardi et al. 2009), whereby a pro-inflammatory surge in gestation can have negative effects on neurogenesis in the offspring (Graciarena et al. 2010). Preterm birth is a further risk factor for the disorder (Rice et al. 2010) and for reduced cortical thickness later in adolescence (Nagy et al. 2011), where this reduction itself is a feature of ADHD (Shaw et al. 2007). Indeed risk factors at birth for the development of ADHD may also include maternal stress, eclampsia, and prolonged labour (Biederman 2005; contrast Barkley et al. 1990). In human and animal models virus infection or exposure to bacterial endotoxins in pregnancy have been associated with altered serotonin metabolism (Winter et al. 2008), increased KA levels (Holtze et al. 2008) and a range of cytokine changes (Romero et al. 2007).

We hypothesised that in peripubertal children with ADHD an echo of some apparent insults on development may still be found with immunological and biochemical measures. This was explored by comparing the retrospective report of features of the pregnancy from mothers of children with and without ADHD, and a preliminary investigation of whether the distribution of these data was in part explained by serum levels of metabolites and cytokines in the offspring.

The results are organized to illustrate first the main group comparisons (group characteristics and symptoms, features of the birth and pre/post-pregnancy periods, and pregnancy-related features). Then, the associations of the metabolite and cytokine levels in the groups of children are considered in turn with a) features of the birth, b) parental smoking habits and alcohol consumption at the time of the pregnancy, c) maternal problems before, during (trimesters 1-3) and after the pregnancy, and d) postnatal child care.

\section{Methods:}

\section{Subjects}

A group of 21 normally developing children were recruited by advertisement to compare with children diagnosed with ADHD combined type (DSM-IV): 21 were newly diagnosed, consecutively referred and medication naïve, while 14 more children had been diagnosed $4 y$ earlier (Müller et al. 2011) and were receiving medication: One was receiving Atomoxetine, one Ritalin and the others a retard formulation (Concerta or Medikinet, 30-40 mg). Exclusion criteria included a history of encephalitis, autism, epilepsy, Tourette syndrome, bipolar disorder, $I Q \leq 80$, brain damage and any genetic or medical condition associated with externalizing behaviours that might mimic ADHD. The protocol, respecting the Declaration of Helsinki, was approved by the ethics committee of the medical faculty of the University of DuisburgEssen. Verbal and written information about the study was given to the children and the parents or guardians who gave written consent to the procedures.

Diagnosis was based on a semistructured interview of the parents (Parental Account of Children's Symptoms; Chen and Taylor 2006; Taylor et al. 1991) on mood disorders, ADHD/hyperkinetic syndrome, disruptive behaviour and additional problems of the children in various structured and unstructured situations (details in Oades et al. 2010a). Symptoms were assessed with the Conners parent and teacher ratings scales (CPRS-R:L, CTRS-R:L: (Conners 2002). Comorbid internalizing and externalizing problems were rated on the anxiety and oppositional subscales: for each group the numbers with $T>65$ on either the CTRS or CPRS, were 9/14 [ADHD], 6/2 [controls], and 6/9 [medicated ADHD] children, respectively. 
Data on gender, age, body-mass index, $I Q$, socio-economic index (SES), reported allergic sensitivities and Conners rating scales are presented in table 1. The IQ was assessed with the standardized version of the CFT-20-R (Weiss 1996) or with the Kaufman battery for children (Kaufman and Kaufman 2001) for those younger than 9 years. The socio-economic scale of the father and mother for profession/ qualification (current and at-birth) were assessed on a scale of 1-7 (Brauns et al. 1997). Allergies of the children in the past (>12 months) and currently experienced were recorded and rated for severity (0-3). The children with ADHD showed $>50 \%$ higher coefficient of reaction time variance on a continuous performance task than the controls (Oades et al. 2010a).

\section{Questionnaire on perinatal features}

The questionnaire concerns the health of the mother and child, and covers 29 features of the course of pregnancy, birth and post-natal circumstances with a total of 124 items that can be scored (Chen et al. 2005). We modified the scoring process by lumping features and rating them from normal over mild and moderate to severe on a scale from 0 to 3 (illustrated in square parentheses in the following). Thus, the course of birth covered interventions (e.g. planned [1] or emergency caesarean section [2], 7 items), the duration of birth (5 stages: [0-3]), foetal complications (e.g. meconium [1], accelerated heart rate [2], resuscitation [3], 4 items) and intensive care (4 stages: [0-3]). The summed ratings for the 4 features were divided by 4 . Three items referred to the doctors' concern over foetal growth and 3 items the potential complications from the mother's side per trimester (e.g. seizures [2], vaginal bleeding [2]). Two items concerned the mother's health before and after pregnancy (e.g. diabetes, hypo/hyperthyroidism, depression [3 each]). Life events that occurred during pregnancy were scored for each trimester (e.g. moving house, loss of loved ones [2]). Dietary supplements during pregnancy were rated as one item (e.g. iron [1], folic acid [2]). No other medications were recorded during pregnancy. There were 2 items on postnatal bottle-feeding and mixed breast/bottle feeding. Lengths of $<3$ months or $>1$ year were scored as ' 1 '; and periods in between as ' 0 '. An item on the infant's health referred to the periods $<5$ months, $<5$ years and $>6$ years (e.g. jaundice [1], fits [2] and meningitis [3]). An item about the family diet concerned the regularity of eating sea food (0 [1+/week] 3 [never]). Smoking (0 [never] - 3 [>16/d]) and drinking alcohol (0 (never) - 3 [>10 units/week]) by both the mother and the father were scored separately for before, during and after pregnancy. A question on recreational drugs revealed only two positive answers and was not included in the analysis. The final question concerned the regularity of a parent reading bedtime stories and helping later with school work (0 [1+/week] - 3 [never]).

\section{Biochemistry}

Briefly, $20 \mathrm{ml}$ fasting venous blood was drawn (8:00-9:00 a.m.), the serum separated and stored at $-80^{\circ} \mathrm{C}$ for analysis blind to the sample's origin (Myint et al. 2007; Oades et al. 2010a). S100B were measured by an immunoluminometric assay (detection limit $0.02 \mu \mathrm{g} / \mathrm{L}$ : ELECSYS $\mathrm{S} 100^{\mathrm{TM}}$, Roche Diagnostics, Switzerland). Serum cytokines IL-2, IL-6, IL-10, IL-13, IL16, IFN- $\gamma$ and TNF- $\alpha$ were analysed with DuoSet ELISA test kits from R\&D systems, UK. Detection limits were $62.5 \mathrm{pg} / \mathrm{ml}$ and intra-assay coefficients of variation were 3.2-5.6\% (details in Oades et al. 2010a).

Analyses for tryptophan, kynurenine and their metabolites (KA, 3HK and 5HIAA) were run in a Waters 2695 chromatograph on a $250 \mathrm{~mm} \times 4 \mathrm{~mm}$ Supersphere 60 RP-select B, C8 column at $35^{\circ} \mathrm{C}$ (Merck, Darmstadt, Germany) with a 2487 dual- $\lambda$ UV detector and a 2475 fluorescence detector. A gradient elution 
for the samples (at $4^{\circ} \mathrm{C}$ ) used a mixture of sodium acetate (pH4.8 to 3.65), acetonitrile and methanol. Tryptophan and 5-HIAA were measured by fluorescence detection ( $\lambda$ ex: $300 \mathrm{~nm}$; $\lambda$ em: $350 \mathrm{~nm}$ and $\lambda$ ex: $300 \mathrm{~nm}$; $\lambda$ em: 340 $\mathrm{nm})$ and kynurenine, $\mathrm{KA}$ and $3 \mathrm{HK}$ were measured by UV detection at 365, 330 and $365 \mathrm{~nm}$, respectively (further details in Myint et al. 2007; Oades et al. 2010a)

\section{Data analysis}

Demographic characteristics and subgroup symptom ratings for the ADHD and control groups are presented in table 1 and compared with corrected 2-tailed Student t-tests. (For a more complete analysis of these data and the biochemical markers see Oades et al. 2010a, b).

Comparisons between ADHD and control groups for the 18 features recorded for the birth, pre/postpregnancy and child care periods are shown in table 2. Table 3 concerns the 9 pregnancy-related items of which 5 had scores relating to each trimester. As there were considerable differences in the homogeneity of variance between these features the group comparisons were examined with t-tests (as above). But the 5 items examined for each trimester (foetal growth, maternal complications and illness, life-events and the taking of medical supplements) were subjected to repeated measures ANOVA for between and within subject changes. Differences at $\alpha \leq 5 \%$ are accepted as significant and at $\alpha$ $=5-10 \%$ are described as trends or tendencies. A few missing values were replaced by the mean.

Associations for pregnancy-related features with metabolite and cytokine measures were sought separately and step-wise with linear backward regressions. Significant contributions in the regression will be referred to as associations or relationships. Significant explanations (F-test, $R^{2}$ and beta) from the biochemical data (tryptophan/metabolites and cytokines) are given for the distribution of birth-related features (table 4), smoking and drinking (table 5), illness, complications, supplements and lifeevents during the pregnancy (table 6) and early child care (table 7) reported. Here analyses for the combined ADHD groups (vs. healthy controls) are shown along with the medication-naive group alone ("no med") to illustrate that despite treatment differences there were often similarities based on the diagnosis rather than differences reflecting medication.

Results are listed if $\alpha \leq 10 \%$ and should be seen in conjunction with the $R^{2}$ estimates of the variance of the pregnancy-related feature explained in the regression equation by the biochemical item. The $R^{2}$ values are measures of effect sizes (coefficients of determination) and are given for each analysis in the tables 47. Where outliers drive the statistical significance of the result this is denoted by a footnote in the table with the biochemical feature identified in the legend. Due to the descriptive character of this preliminary, pilot-study corrections for the number of regression analyses performed are not reported.

\section{Results}

\section{Group comparisons - group characteristics and symptoms}

The ADHD and control groups did not differ significantly on age, body mass index, experience of allergy or gender representation. As would be expected the ADHD group did show a lower prorated IQ and a tendency to come from families with a lower SES (table 1). The ADHD groups showed significantly more severe symptoms on both parental and teacher ratings according to oppositional, inattentive, hyperactive-impulsive and total scores: but, higher ratings of anxiety in the ADHD group attained only borderline significance (table 1 ). 
Table 1:

Characteristics of the ADHD and control groups (mean, standard deviation, SD) and the Conners' parent (CPRS) and teacher (CTRS) symptom ratings (mean, standard error, SEM)

\begin{tabular}{|c|c|c|c|c|c|}
\hline & $\begin{array}{l}\text { ADHD } \\
\text { mean } \\
n=35\end{array}$ & $S D$ & $\begin{array}{l}\text { Control } \\
\text { mean } \\
\mathrm{n}=21\end{array}$ & $S D$ & $\begin{array}{l}\text { t-test }{ }^{1} \\
\text { p value }\end{array}$ \\
\hline Gender (m/f) & $26 / 9$ & & $20 / 1$ & & \\
\hline Age (y) & 10.4 & 2.5 & 11.0 & 1.5 & \\
\hline IQ & 100.2 & 12.4 & 114.1 & 14.4 & $\mathrm{p}<.001$ \\
\hline Body mass index & 18.1 & 3.9 & 17.9 & 3.1 & \\
\hline Allergy (N/grade) & $10 / 0.6$ & 1.1 & $11 / 0.8$ & 0.9 & \\
\hline SES M birth & 4.0 & 1.5 & 3.6 & 0.8 & \\
\hline SES M current & 4.1 & 1.6 & 3.3 & 1.4 & $\mathrm{p}=.06$ \\
\hline SES F birth & 4.3 & 2.1 & 3.3 & 2.0 & $\mathrm{p}=.07$ \\
\hline SES F current & 4.2 & 2.1 & 3.5 & 2.1 & \\
\hline CPRS & $\begin{array}{l}\text { mean } \\
n=34\end{array}$ & SEM & $\begin{array}{l}\text { mean } \\
n=21\end{array}$ & SEM & $\mathrm{t}$-test ${ }^{2}$ \\
\hline - Opposition & 71.4 & 1.7 & 51.7 & 1.2 & $\mathrm{p}<.000$ \\
\hline - Anxiety & 57.0 & 1.9 & 51.1 & 1.9 & $\mathrm{p}=.04$ \\
\hline - DSM-IA & 71.0 & 1.9 & 47.8 & 1.0 & $\mathrm{p}<.000$ \\
\hline - DSM-HI & 76.2 & 1.8 & 48.1 & 0.9 & $\mathrm{p}<.000$ \\
\hline - DSM-sum & 74.9 & 1.6 & 48.0 & 0.9 & $\mathrm{p}<.000$ \\
\hline \multicolumn{6}{|l|}{ CTRS } \\
\hline - Opposition & 60.4 & 2.3 & 50.8 & 2.1 & $\mathrm{p}=.004$ \\
\hline - Anxiety & 61.1 & 2.2 & 54.8 & 2.5 & $\mathrm{p}=.06$ \\
\hline - DSM-IA & 63.5 & 2.3 & 48.6 & 1.5 & $\mathrm{p}<.000$ \\
\hline - DSM-HI & 61.2 & 2.7 & 48.4 & 1.9 & $\mathrm{p}=.001$ \\
\hline - DSM-sum & 63.7 & 2.3 & 48.5 & 1.7 & $\mathrm{p}<.000$ \\
\hline
\end{tabular}

$\mathrm{SES}=$ socio-economic scale (rated 1-7):

Bonferroni correction of $\alpha=5 \%: 1 . p=0.0063$, 2. $\mathrm{p}=0.005$

\section{Group comparisons - features of the birth and pre/post-pregnancy periods}

At birth there were modest trends for the children with ADHD to have been borne sooner, to have weighed less and experienced more complications at birth than the healthy controls (table 2). APGAR values did not differ significantly. In the period before the pregnancy mothers of ADHD children consumed more alcohol and after the pregnancy the fathers of ADHD children smoked more than their control counterparts. There were no group differences between the mothers' history of stillbirths, incidence of illness before or after pregnancy nor in the mothers' post-pregnancy consumption of alcohol or nicotine. In the postnatal child care period there were no differences in infant health, for coarse measures of the duration of breast-feeding or the proportion of bottle-feeding. Unexpectedly, the degree of time spent together (e.g. reading) was descriptively less in control families, and similarly fish tended to be represented less in the diet of control families.

\section{Group comparisons - pregnancy- related features}

Repeated measures analyses showed no within or between group differences for foetal growth, life events or maternal illnesses across the 3 trimesters (table 3 ). Smoking and drinking habits across the pregnancy did not differ between the two family groups. Marginally more frequent in $\mathrm{T} 1$ were pregnancy-complications for control mothers and the prescription of supplements or medications for mothers in the ADHD group.

\section{Metabolite and cytokine associations - features of the birth}

Increasing levels of $3 \mathrm{HK}$ (and no other metabolite) related consistently to shorter periods of gestation, lower birth weight and lower APGAR values in the full ADHD group, supported by data from the nonmedicated group. There were no associations of tryptophan metabolites with problems experienced at birth or for a history of stillbirths, and there were no relationships for the controls (table 4a). These results should be seen against the background of $3 \mathrm{HK}$ levels being on average about $10 \%$ lower in the ADHD than in the control children.

Among the cytokines, decreasing levels of TNF- $\alpha$ contributed prominently to the distribution of reports of a shorter gestation, decreased birth weight and more problems at birth in the ADHD group (table 4b). This influence was modestly supported by associations with increasing levels of IFN- $\gamma$ for shorter gestation and lower APGAR values. Some of these effects 
Table 2 Maternal assessment of birth problems, pre- and post-pregnancy features

(Mean and standard error, SEM)

\begin{tabular}{|c|c|c|c|c|c|}
\hline \multirow{2}{*}{$\begin{array}{l}\text { Group: } \\
\text { Measure: }\end{array}$} & \multicolumn{2}{|l|}{ ADHD } & \multicolumn{2}{|c|}{ Controls } & \multirow[b]{2}{*}{ significance } \\
\hline & mean $(n=33-35)$ & SEM & mean $(n=21)$ & SEM & \\
\hline Pregnancy (weeks) & 38.86 & 0.34 & 39.70 & 0.24 & $\mathrm{p}=.050$ \\
\hline Birth weight (class) $^{1}$ & 0.34 & 0.12 & 0.10 & 0.07 & $\mathrm{p}=.068$ \\
\hline APGAR (first) & 9.38 & 0.20 & 9.74 & 0.13 & \\
\hline Course of birth ${ }^{2}$ & 0.58 & 0.08 & 0.37 & 0.09 & $\mathrm{p}=.099$ \\
\hline History of still-births ${ }^{3}$ & 0.42 & 0.14 & 0.57 & 0.20 & \\
\hline \multicolumn{6}{|l|}{ Pre-pregnancy } \\
\hline Illness (M) ${ }^{4}$ & 0.39 & 0.17 & 0.10 & 0.10 & \\
\hline Alcohol (M) ${ }^{5}$ & 0.55 & 0.12 & 0.19 & 0.09 & $\mathrm{p}=.018$ \\
\hline Smoking (M) ${ }^{6}$ & 1.30 & 0.24 & 0.81 & 0.26 & \\
\hline Smoking $(F)^{6}$ & 1.87 & 0.25 & 1.2 & 0.31 & \\
\hline \multicolumn{6}{|l|}{ Post-pregnancy } \\
\hline Illness (M) ${ }^{4}$ & 0.58 & 0.20 & 0.48 & 0.20 & \\
\hline Alcohol (M) ${ }^{5}$ & 0.49 & 0.11 & 0.52 & 0.13 & \\
\hline Smoking (M) ${ }^{6}$ & 0.91 & 0.22 & 0.57 & 0.23 & \\
\hline Smoking (F) & 1.58 & 0.25 & 0.81 & 0.27 & $\mathrm{p}=.044$ \\
\hline \multicolumn{6}{|l|}{ Child care } \\
\hline Infant health ${ }^{7}$ & 0.91 & 0.14 & 0.67 & 0.21 & \\
\hline Breast/bottle & 0.53 & 0.09 & 0.48 & 0.11 & \\
\hline Bottle-feed ${ }^{8}$ & 0.18 & 0.07 & 0.24 & 0.09 & \\
\hline Fish-in-diet ${ }^{9}$ & 1.03 & 0.14 & 1.52 & 0.22 & $\mathrm{p}=.056$ \\
\hline Read-together ${ }^{10}$ & 0.27 & 0.11 & 0.43 & 0.19 & \\
\hline
\end{tabular}

1. $>2800$ [rated 0], - 2300 [1], -1800 [2], $<1800$ g [3]

2. Rated 0-3 e.g. duration, forceps, suction, breach birth, heart rate, meconium, umbilical cord, planned caesarean

3. Previous miscarriages, no/yes [rated $0 / 2$ ]

4. Illnesses e.g. diabetes, hypo/hyperthyroidism, depression, anxiety [rated 3 each]

5. 0, 1-2, 3-10, >10 units/week [rated 0-3]

6. $0,-5,-15,>15 /$ day [rated $0-3$ ]

7. Infant health e.g. jaundice [1], fits, anaemia, growth problems [2], encephalitis/meningitis [3]

8. Mixed breast $\&$ bottle or only bottle feed: $3-12$ months [0], $<3$ months $/>12$ months [1]

9. Sea food eaten: ca. daily/weekly [0], monthly [1], 1-2x/year [2], not at all [3]

10. Reading together was rated as for ' 9 ' above: $M$ - Mother, F - Father

were partially confirmed in the smaller, non-medicated group. These results may be viewed against a background where TNF- $\alpha$ and IFN- $\gamma$ levels were marginally increased in the ADHD group but were lower in the medicated group (matching control levels). S100B levels tended to increase with low birth weight and short gestation, but there was a modest negative trend in controls suggesting a protective relationship for decreasing S100B levels with a history of stillbirths.

Metabolite and cytokine associations smoking habits and alcohol consumption

Although maternal alcohol consumption at any stage was unrelated to levels of tryptophan metabolites in the children, smoking habits showed differential associations depending on parent and group (table 5a). In the ADHD group increased maternal smoking during pregnancy was associated with increasing $3 \mathrm{HK}$ levels and decreasing kynurenine levels in the children. The opposite effect seemed to emerge in controls, although the regressions were driven by outliers. In contrast, paternal smoking in control families was associated with increasing tryptophan levels.

Levels of a number of cytokines appeared to relate to alcohol consumption, but most results were driven by outliers (table $5 b$ ). There was an 
Table 3 Maternal assessment of features of each pregnancy trimester (T1, T2 and T3)

(Mean and standard error, SEM)

\begin{tabular}{|c|c|c|c|c|c|c|}
\hline \multirow{2}{*}{ Measure: } & \multicolumn{2}{|l|}{ ADHD } & \multicolumn{4}{|c|}{ Controls } \\
\hline & mean $(n=33-35)$ SEN & & mean $(n=21)$ & SEM & signific & nce \\
\hline \multicolumn{7}{|l|}{ Child growth $^{1}$} \\
\hline $\mathrm{T} 1$ & 0 & 0 & 0.05 & & 0.05 & \\
\hline $\mathrm{T} 2$ & 0.03 & 0.03 & 0.05 & & 0.05 & \\
\hline T3 & 0.06 & 0.06 & 0.05 & & 0.05 & \\
\hline \multicolumn{7}{|l|}{ Life events ${ }^{2}$} \\
\hline $\mathrm{T} 1$ & 0.36 & 0.14 & 0.24 & & 0.14 & \\
\hline $\mathrm{T} 2$ & 0.48 & 0.15 & 0.48 & & 0.19 & \\
\hline T3 & 0.39 & 0.14 & 0.24 & & 0.14 & \\
\hline \multicolumn{7}{|c|}{ Maternal complications ${ }^{3}$} \\
\hline $\mathrm{T} 1$ & 0.12 & 0.08 & 0.48 & & 0.19 & $\mathrm{p}=.0$ \\
\hline $\mathrm{T} 2$ & 0.24 & 0.12 & 0.43 & & 0.20 & \\
\hline T3 & 0.36 & 0.14 & 0.57 & & 0.20 & \\
\hline \multicolumn{7}{|l|}{ Illnesses ${ }^{4}$} \\
\hline $\mathrm{T} 1$ & 0.52 & 0.17 & 0.38 & & 0.19 & \\
\hline $\mathrm{T} 2$ & 0.36 & 0.16 & 0.48 & & 0.21 & \\
\hline $\mathrm{T} 3$ & 0.39 & 0.15 & 0.29 & & 0.17 & \\
\hline \multicolumn{7}{|c|}{ Medical supplements ${ }^{5}$} \\
\hline $\mathrm{T} 1$ & 1.00 & 0.17 & 0.57 & & 0.13 & $\mathrm{p}=.0$ \\
\hline $\mathrm{T} 2$ & 0.97 & 0.17 & 0.67 & & 0.16 & \\
\hline T3 & 0.85 & 0.17 & 0.62 & & 0.18 & \\
\hline M smoking $^{6}$ & 0.52 & 0.15 & 0.48 & & 0.20 & \\
\hline F smoking & 1.77 & 0.26 & 1.14 & & 0.30 & \\
\hline Alcohol $^{6}$ & 0.09 & 0.05 & 0.10 & & 0.07 & \\
\hline Substance use ${ }^{7}$ & 0.09 & 0.09 & 0.05 & & 0.05 & \\
\hline
\end{tabular}

1. Concern over foetal growth: none/minor/serious [rated 0-2]

2. Life events (move house, accident, loss of loved ones, trauma) [rated 2 if present]

3. Potential pregnancy complications (seizures, blood pressure, vaginal bleed, anaemia [rated 2 if present]

4. Minor illness: influenza [1], several [2], or more serious [3] e.g. diabetes, hypo/hyperthyroidism, depression

5. Prescribed supplements or medications: iron, vitamins [1], folic acid [2], psychotropic agents [3]

6. Smoking and alcohol intake frequency (see table 2)

7. Recreational drug-use (THC-elated [1], amphetamine related [2], cocaine/heroin-related [3] $\mathrm{M}$ - Mother, F - Father

indication that increased drinking after the pregnancy was associated with increasing IL-16 and IFN- $\gamma$ levels in the ADHD group, with decreasing IL-16 levels being relevant for the controls.

The most consistent relationship for maternal smoking in the ADHD groups (at each stage) was a positive one with S100B. For paternal smoking in ADHD families the most consistent relationship at each stage was positive with IL6 levels. There were no clear-cut relationships for smoking in control families, with tendencies being driven by outliers (table $5 b$ ).

Metabolite and cytokine associations trimester-related problems and pre/post-pregnancy illness
Considering other features that might directly relate to foetal health, at the group level only two tended to distinguish mothers of ADHD and control children. Mothers of healthy children exhibited more complications in $\mathrm{T} 1$, but they took fewer supplements or medications in T1 compared to mothers of children that developed ADHD.

Elements of the "serotonin pathway" may be relevant for associations with these features. Decreasing levels of the metabolite 5-HIAA in children with ADHD reflected the early experience of life events (T1) and the use of supplements (T2) (table 6a). Decreasing levels of the precursor tryptophan were associated with fewer complications later (T3). 
Table 4 Regressions of birth-related features by a) tryptophan metabolites and b) cytokines

\begin{tabular}{|c|c|c|c|c|c|c|}
\hline A/ Group & Feature & Metabolite & F-test & $\mathbf{R}^{2}$ & beta & significance (p) \\
\hline $\begin{array}{l}\text { ADHD } \\
\text { No med } \\
\text { Controls }\end{array}$ & $\underline{\text { Gestation }}$ & $\begin{array}{r}3 \mathrm{HK} \\
3 \mathrm{HK} \\
--\end{array}$ & $\begin{array}{l}\mathrm{F}(1,33)=6.24 \\
\mathrm{~F}(1,19)=5.82 \\
\text { ns ----- }\end{array}$ & $\begin{array}{l}0.16 \\
0.23\end{array}$ & $\begin{array}{l}-0.40 \\
-0.48\end{array}$ & $\begin{array}{l}.018 \\
.026\end{array}$ \\
\hline $\begin{array}{l}\text { ADHD } \\
\text { No med } \\
\text { Controls }\end{array}$ & $\underline{\text { Birth weight }}$ & $\begin{array}{r}3 \mathrm{HK} \\
3 \mathrm{HK} \\
--\end{array}$ & $\begin{array}{l}F(1,33)=7.48 \\
F(1,19)=3.27 \\
\text { ns ----- }\end{array}$ & $\begin{array}{l}0.19 \\
0.30\end{array}$ & $\begin{array}{l}+0.43 \\
+0.55\end{array}$ & $\begin{array}{l}.010 \\
.010\end{array}$ \\
\hline $\begin{array}{l}\text { ADHD } \\
\text { No med }{ }^{1} \\
\text { Controls }\end{array}$ & $\underline{\text { APGAR }}$ & $3 \mathrm{HK}$ & $\begin{array}{l}\mathrm{F}(1,33)=11.93 \\
\text { ns .... }\end{array}$ & 0.27 & -0.52 & .002 \\
\hline $\begin{array}{l}\text { ADHD } \\
\text { No med } \\
\text { Controls } \\
\text { ADHD } \\
\text { No med } \\
\text { Controls }\end{array}$ & History still-b & irth - & ns ..... & & & \\
\hline B/ Group & Feature & Cytokine & F-test & $\mathbf{R}^{2}$ & beta & significance (p) \\
\hline $\begin{array}{l}\text { No med } \\
\text { Controls }\end{array}$ & $\underline{\text { Gestation }}$ & $\begin{array}{l}\text { TNF- } \alpha \\
\text { IL-6 } \\
\text { IFN- } \gamma \\
\text { S100B } \\
\quad--\end{array}$ & $\begin{array}{l}\mathrm{F}(2,18)=4.72 \\
\text { ns } \ldots \ldots\end{array}$ & 0.34 & $\begin{array}{l}+0.54 \\
+0.40 \\
-0.41 \\
-0.52\end{array}$ & $\begin{array}{l}.003 \\
.011 \\
.018 \\
.016\end{array}$ \\
\hline $\begin{array}{l}\text { ADHD } \\
\text { No med } \\
\text { Controls }\end{array}$ & $\underline{\text { Birth weight }}$ & $\begin{array}{c}\text { TNF- } \alpha \\
\text { S100B } \\
\text { S100B } \\
--\end{array}$ & $\begin{array}{l}F(2,32)=12.46 \\
F(3,17)=12.03 \\
\text { ns } \ldots \ldots\end{array}$ & $\begin{array}{l}0.44 \\
0.68\end{array}$ & $\begin{array}{l}-0.53 \\
+0.30 \\
+0.58\end{array}$ & $\begin{array}{l}.001 \\
.034 \\
.001\end{array}$ \\
\hline $\begin{array}{l}\text { ADHD } \\
\text { No med } \\
\text { Controls }\end{array}$ & $\underline{\text { APGAR }}$ & $\begin{array}{l}\text { IFN- } \gamma \\
\text { IFN- } \gamma\end{array}$ & $\begin{array}{l}F(1,33)=4.43 \\
F(1,19)=3.21\end{array}$ & $\begin{array}{l}0.19 \\
0.15\end{array}$ & $\begin{array}{l}-0.34 \\
-0.38\end{array}$ & $\begin{array}{l}.043 \\
.089\end{array}$ \\
\hline ADHD & $\underline{\text { Course of birth }}$ & $\begin{array}{l}\text { TNF- } \alpha \\
\text { IL-13 }\end{array}$ & $F(2,32)=3.18$ & 0.17 & $\begin{array}{l}-0.43 \\
+0.44\end{array}$ & $\begin{array}{l}.035 \\
.031\end{array}$ \\
\hline $\begin{array}{l}\text { No med } \\
\text { Controls }\end{array}$ & & $\begin{array}{l}-- \\
--\end{array}$ & $\begin{array}{l}\text { ns ..... } \\
\text { ns ..... }\end{array}$ & & & \\
\hline $\begin{array}{l}\text { ADHD } \\
\text { No med } \\
\text { Controls }\end{array}$ & History stillbi & $\begin{array}{c}\underline{\text { irth }}-- \\
\text { S100B }\end{array}$ & $\begin{array}{l}\text { ns } \ldots \ldots \\
\text { ns } \ldots \ldots \\
\mathrm{F}(1,19)=3.23\end{array}$ & 0.15 & -0.38 & .080 \\
\hline
\end{tabular}

$\mathrm{ADHD}=$ the full group of 35 , no med refers to the 21 non-medicated ADHD children:

$\mathrm{M}=$ Mother, $\mathrm{F}=$ Father; $\mathrm{ns}=$ non-significant. Footnotes, significant but characterised by extreme values: 1. 3HK, 2. IFN- $\gamma$, 3. TNF- $\alpha$, IFN- $\gamma, 4$. IL-13

However, increasing levels of the neuroprotective metabolite KA in children with ADHD was associated with more frequent life events late in the pregnancy (T3). Maternal illness before or after the pregnancy was not related to metabolite levels in either group (table 6a).

Considering the cytokines, the principle associations concern the taking of supplements by mothers of ADHD children in T1 and T3. Children's levels of the proinflammatory TNF- $\alpha$ decreased and of the anti-inflammatory IL-10 increased with maternal supplement use. These associations were supported in the nonmedicated children. Other results (table $6 \mathrm{~b}$ footnotes and legend) reflected 
Table 5 Regression of smoking and drinking by a) tryptophan metabolites and b) cytokines

\begin{tabular}{|c|c|c|c|c|c|c|}
\hline A/ Group & Feature & Metabolite & F-test & $\mathbf{R}^{2}$ & beta & significance (p) \\
\hline $\begin{array}{l}\text { ADHD } \\
\text { No med } \\
\text { Controls }\end{array}$ & $\begin{array}{l}\text { M smoke } \\
\text { pre- } \\
\text { pregnancy }\end{array}$ & & ns ..... & & & \\
\hline $\begin{array}{l}\text { ADHD } \\
\text { No med } \\
\text { Controls }^{1}\end{array}$ & $\begin{array}{l}\text { M smoke } \\
\text { in } \\
\text { pregnancy }\end{array}$ & $\begin{array}{l}3 \mathrm{HK} \\
3 \mathrm{HK}\end{array}$ & $\begin{array}{l}F(1,34)=3.76 \\
F(1,19)=4.90\end{array}$ & $\begin{array}{l}0.10 \\
0.21\end{array}$ & $\begin{array}{l}+0.32 \\
+0.45\end{array}$ & $\begin{array}{l}.061 \\
.039\end{array}$ \\
\hline $\begin{array}{l}\text { ADHD } \\
\text { No med } \\
\text { Controls }\end{array}$ & $\begin{array}{l}\text { M smoke } \\
\text { post- } \\
\text { pregnancy }\end{array}$ & $\begin{array}{c}-- \\
\text { kynurenine }\end{array}$ & $\begin{array}{l}\text { ns } \ldots \ldots \\
\mathrm{F}(1,19)=4.77\end{array}$ & 0.20 & -0.45 & .042 \\
\hline $\begin{array}{l}\text { ADHD } \\
\text { No med } \\
\text { Controls }\end{array}$ & $\begin{array}{l}\frac{\text { F smoke }}{\text { pre- }} \\
\text { pregnancy }\end{array}$ & tryptophan & $F(1,19)=14.0$ & 0.43 & +0.65 & .001 \\
\hline $\begin{array}{l}\text { ADHD } \\
\text { No med } \\
\text { Controls }\end{array}$ & $\begin{array}{l}\frac{\text { F smoke }}{\text { in }} \\
\text { pregnancy }\end{array}$ & tryptophan & $F(1,19)=10.7$ & 0.36 & +0.60 & .004 \\
\hline $\begin{array}{l}\text { ADHD } \\
\text { No med } \\
\text { Controls }\end{array}$ & $\begin{array}{l}\text { F smoke } \\
\text { post- } \\
\text { pregnancy }\end{array}$ & $\begin{array}{l}\text {-- } \\
\text { kynurenine } \\
\text { tryptophan }\end{array}$ & $\begin{array}{l}\text { ns } \ldots . . \\
F(1,19)=5.80 \\
F(1,19)=6.21\end{array}$ & $\begin{array}{l}0.23 \\
0.25\end{array}$ & $\begin{array}{l}-0.48 \\
+0.25\end{array}$ & $\begin{array}{l}.026 \\
.022\end{array}$ \\
\hline
\end{tabular}

ADHD/no med/controls $\underline{M}$ alcohol pre-, in \& post-pregnancy $n s$....

\begin{tabular}{|c|c|c|c|c|c|c|}
\hline B/ Group & Feature & Cytokine & F-test & $\mathbf{R}^{2}$ & beta & significance (p) \\
\hline $\begin{array}{l}\text { ADHD } \\
\text { No med }\end{array}$ & $\frac{\text { M smoke }}{\text { pre }}$ & S100B & $F(1,33)=3.64$ & 0.10 & +0.32 & .065 \\
\hline Controls & pregnancy & IL-2 & $F(1,19)=5.11$ & 0.21 & +0.46 & .036 \\
\hline ADHD $^{3}$ & $\underline{M}$ smoke & S100B & $F(3,31)=7.45$ & 0.42 & +0.48 & .002 \\
\hline No med & in & IL-16 & $F(1,19)=4.24$ & 0.18 & +0.43 & .053 \\
\hline Controls & pregnancy & -- & $\mathrm{ns} \ldots \ldots$ & & & \\
\hline ADHD & $\underline{\text { M smoke }}$ & S100B & $F(1,33)=3.63$ & 0.10 & +0.32 & .065 \\
\hline No med & post- & -- & ns ..... & & & \\
\hline Controls & pregnancy & -- & ns ..... & & & \\
\hline ADHD & $\underline{\text { F smoke }}$ & IL-6 & $F(1,33)=4.24$ & 0.11 & +0.34 & .047 \\
\hline No med & pre- & IL-6 & $F(1,19)=4.57$ & 0.19 & +0.44 & .046 \\
\hline Controls & pregnancy & S100B & $F(1,19)=3.19$ & 0.14 & +0.38 & .090 \\
\hline ADHD & $\underline{\text { F smoke }}$ & IL-6 & $F(1,33)=5.98$ & 0.15 & +0.39 & .020 \\
\hline $\begin{array}{l}\text { No med } \\
\text { Controls }\end{array}$ & $\begin{array}{l}\text { in } \\
\text { pregnancy }\end{array}$ & IL-6 & $F(1,19)=5.73$ & 0.23 & +0.48 & .027 \\
\hline ADHD & $\underline{\text { F smoke }}$ & IL-6 & $F(1,33)=6.68$ & 0.17 & +0.41 & .014 \\
\hline No med & after & IL-6 & $F(1,19)=6.58$ & 0.26 & +0.51 & .019 \\
\hline Controls & pregnancy & & ns ..... & & & \\
\hline
\end{tabular}

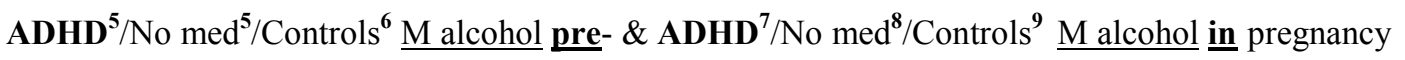

$\begin{array}{lllllll}\text { ADHD } & \text { M alcohol } & \text { IL-16 } & \text { F 2,32)=5.85 } & 0.27 & +0.31 & .047 \\ \begin{array}{l}\text { No med }{ }^{10} \\ \text { Controls }^{11}\end{array} & \begin{array}{l}\text { post- } \\ \text { pregnancy }\end{array} & \text { IFN- } \gamma & & & +0.41 & .012 \\ & & \text { IL-16 } & \text { F (2,18)=14.27 } & 0.61 & -0.83 & .000\end{array}$

Abbreviations see table 4. 1. kynurenine, 3HK; 2. S100B, IL-13; 3. IL-2, IFN- $\gamma$; 4. IL-13; 5. S100B; 6. TNF- $\alpha$; 7. IL-16; S100B; 8. S100B, TNF- $\alpha$; 9. IL-13; 10. S100B, TNF- $\alpha$; 11. IFN- $\gamma$ 
Table 6 Regression of illness, complications and supplements by a) metabolites, b) cytokines

\begin{tabular}{|c|c|c|c|c|c|c|}
\hline A/ Group & Feature & Metabolite & F-test & $\mathbf{R}^{2}$ & beta & significance (p) \\
\hline $\begin{array}{l}\text { ADHD } \\
\text { No med } \\
\text { Controls }\end{array}$ & $\begin{array}{l}\text { pre-/post- } \\
\text { pregnancy illness }\end{array}$ & $\begin{array}{l}-- \\
-- \\
--\end{array}$ & $\begin{array}{l}\mathrm{ns} \ldots \ldots \\
\mathrm{ns} \ldots \ldots \\
\mathrm{ns} \ldots \ldots\end{array}$ & & & \\
\hline $\begin{array}{l}\text { ADHD } \\
\text { No med } \\
\text { Controls }\end{array}$ & $\begin{array}{l}\text { M T3 illness/ } \\
\underline{\text { complications }}\end{array}$ & $\begin{array}{c}\text { tryptophan } \\
-- \\
--\end{array}$ & $\begin{array}{l}\mathrm{F}(1,33)=6.44 \\
\text { ns } \ldots \ldots \\
\text { ns } \ldots . .\end{array}$ & 0.16 & +0.41 & .016 \\
\hline $\begin{array}{l}\text { ADHD } \\
\text { No med } \\
\text { Controls }\end{array}$ & $\begin{array}{l}\text { M T1/T2 illness/ } \\
\underline{\text { complications }}\end{array}$ & $\begin{array}{l}-- \\
-- \\
--\end{array}$ & $\begin{array}{l}\text { ns } \ldots \ldots \\
\text { ns } \ldots \ldots \\
\text { ns } \ldots \ldots\end{array}$ & & & \\
\hline $\begin{array}{l}\text { ADHD } \\
\text { No med } \\
\text { Controls }^{1}\end{array}$ & T2 supplements & $\begin{array}{c}\text { 5-HIAA } \\
--\end{array}$ & $\begin{array}{l}\mathrm{F}(1,34)=2.90 \\
\text { ns } \ldots \ldots\end{array}$ & 0.08 & -0.28 & .098 \\
\hline $\begin{array}{l}\text { ADHD } \\
\text { No med } \\
\text { Controls }\end{array}$ & T1/T3 supplements & -- & ns ..... & & & \\
\hline $\begin{array}{l}\text { ADHD }^{2} \\
\text { No med } \\
\text { Controls }\end{array}$ & $\underline{\text { T1 life events }}$ & $\begin{array}{c}\text { 5-HIAA } \\
--\end{array}$ & $\begin{array}{l}\mathrm{F}(1,19)=6.26 \\
\mathrm{~ns} \ldots \ldots\end{array}$ & 0.25 & -0.50 & .022 \\
\hline
\end{tabular}

ADHD/no med/controls

\begin{tabular}{|c|c|c|c|c|c|c|}
\hline \multirow{2}{*}{\multicolumn{2}{|c|}{$\begin{array}{l}\text { ADHD } \\
\text { No } \mathrm{med}^{3} / \text { Controls }\end{array}$}} & \multirow{2}{*}{ KA } & \multicolumn{4}{|l|}{ ns ...... } \\
\hline & & & $\begin{array}{l}\mathrm{F}(1,33)=3.22 \\
\mathrm{~ns} \ldots \ldots\end{array}$ & 0.09 & +0.30 & .082 \\
\hline B/ Group & Feature & Cytokine & F-test & $\mathbf{R}^{2}$ & beta & significance (p) \\
\hline ADHD/no med/Controls ${ }^{4}$ & pre-pregnancy il & $\underline{\operatorname{lness}}$ & ns $\ldots .$. & & & \\
\hline \multicolumn{7}{|c|}{ ADHD $^{5} /$ No med $^{5} /$ Controls $^{6}$ post-pregnancy illness } \\
\hline ADHD/No med/Controls ${ }^{7}$ & \multicolumn{2}{|c|}{$\underline{\mathrm{T} 1 \mathrm{~T} 2 \text { complications }}$} & \multicolumn{4}{|l|}{ ns ..... } \\
\hline ADHD/No med /Controls & \multicolumn{2}{|l|}{$\underline{\text { T3 complications }}$} & \multicolumn{4}{|l|}{ ns $\ldots .}$. \\
\hline ADHD & $\underline{\text { T1 supplements }}$ & $\begin{array}{l}\text { TNF- } \alpha \\
\text { IFN- } \gamma \\
\text { IL-10 }\end{array}$ & $F(3,34)=5.76$ & 0.36 & $\begin{array}{l}-0.38 \\
+0.37 \\
+0.42\end{array}$ & $\begin{array}{l}.024 \\
.030 \\
.008\end{array}$ \\
\hline No med & & $\begin{array}{l}\text { TNF- } \alpha \\
\text { IL-10 }\end{array}$ & $F(1,18)=3.67$ & 0.16 & $\begin{array}{l}-0.43 \\
+0.53\end{array}$ & $\begin{array}{l}.051 \\
.017\end{array}$ \\
\hline Controls & & -- & ns $\ldots .$. & & & \\
\hline ADHD/No med /Controls & \multicolumn{2}{|l|}{ s T2 supplements } & \multicolumn{4}{|l|}{ ns $\ldots .}$. \\
\hline ADHD & $\underline{\text { T3 supplements }}$ & $\begin{array}{l}\text { TNF- } \alpha \\
\text { IL-10 }\end{array}$ & $F(2,32)=6.83$ & 0.30 & $\begin{array}{l}-0.42 \\
+0.43\end{array}$ & $\begin{array}{l}.009 \\
.008\end{array}$ \\
\hline No med & & $\begin{array}{l}\text { TNF- } \alpha \\
\text { IL-10 }\end{array}$ & $F(2,18)=4.99$ & 0.36 & $\begin{array}{l}-0.58 \\
+0.41\end{array}$ & $\begin{array}{l}.009 \\
.056\end{array}$ \\
\hline Controls & & -- & ns $\ldots .$. & & & \\
\hline \multicolumn{3}{|c|}{ ADHD/No med /Controls ${ }^{8} \underline{\text { T1 life events }}$} & \multicolumn{4}{|l|}{ ns $\ldots .}$. \\
\hline ADHD/No med ${ }^{9} /$ Controls & \multicolumn{2}{|l|}{$\underline{\mathrm{T} 2 \text { life events }}$} & \multicolumn{4}{|l|}{ ns ....... } \\
\hline $\mathbf{A D H D}^{\mathbf{1 0}} /$ No med/Controls & $\underline{\text { T3 life events }}$ & & ns ..... & & & \\
\hline
\end{tabular}


Table 7 Regression of child care features by a) tryptophan metabolites and b) cytokines

\begin{tabular}{|c|c|c|c|c|c|c|}
\hline A/ Group & Feature & Metabolite & F-test & $\mathbf{R}^{2}$ & beta & significance (p) \\
\hline ADHD & $\underline{\text { Infant }}$ & 5-HIAA & $F(1,32)=2.97$ & 0.08 & +0.29 & .094 \\
\hline No med & $\underline{\text { health }}$ & -- & ns .... & & & \\
\hline Controls & & -- & ns ..... & & & \\
\hline ADHD & Fish in diet & tryptophan & $F(1,32)=2.61$ & 0.08 & +0.27 & .111 \\
\hline No med & & -- & ns $\ldots \ldots$ & & & \\
\hline Controls & & -- & ns ..... & & & \\
\hline ADHD & $\underline{\text { Read-together }}$ & tryptophan & $\mathrm{F}(1,33)=3.89$ & 0.11 & +0.33 & .057 \\
\hline No med & & -- & ns .... & & & \\
\hline Controls & & -- & ns ..... & & & \\
\hline B/ Group & Feature & Cytokine & F-test & $\mathbf{R}^{2}$ & beta & significance (p) \\
\hline $\begin{array}{l}\text { ADHD } \\
\text { No med }\end{array}$ & Infant health & -- & ns ..... & & & \\
\hline Controls & & IL-16 & $F(1,19)=4.45$ & 0.19 & +0.44 & .048 \\
\hline ADHD $^{1}$ & $\underline{\text { Fish in diet }}$ & IL-2 & $F(3,31)=6.46$ & 0.39 & -0.43 & .011 \\
\hline No med ${ }^{2}$ & & $\begin{array}{l}\text { IFN- } \gamma \\
\text { IFN- } \gamma\end{array}$ & $\mathrm{F}(2.18)=5.71$ & 0.39 & $\begin{array}{l}-0.43 \\
-0.59\end{array}$ & $\begin{array}{l}.012 \\
.006\end{array}$ \\
\hline Controls & & IFN- $\gamma$ & $F(1,19)=3.50$ & 0.16 & +0.39 & .077 \\
\hline $\mathrm{ADHD}^{3}$ & $\underline{\text { Read together }}$ & S100B & $F(2,32)=4.05$ & 0.20 & -0.34 & .045 \\
\hline No med & & IL-6 & $F(1,19)=5.16$ & 0.21 & +0.46 & .035 \\
\hline Controls ${ }^{4}$ & & S100B & $F(3,17)=2.66$ & 0.32 & +0.56 & .025 \\
\hline
\end{tabular}

Abbreviations see table 4. 1. TNF- $\alpha$; 2. S100B; 3. IL-6; 4. IL-6 (negative beta), IL-10

a few extreme cases rather than consistent quantitative relationships between cytokine levels and complications or life events experienced in pregnancy.

\section{Metabolite and cytokine associations - child care}

There were non-significant trends for young children from ADHD families to experience poorer health as infants, but later consume more seafood and spend more time together with their parent(s) (table 2). There were modest tendencies for tryptophan levels to decrease in the ADHD group with the consumption of seafood and time spent with parents, but for 5-HIAA levels to increase with poor infant health (table 7a).

Poor infant health in the ADHD group was also modestly related to increasing levels of IL-16 (table 7b), a cytokine previously related to their sensitivity to allergy (Oades et al., 2010b). The putatively beneficial increase of fish in the diet of these children was reflected by modest increases of the pro-inflammatory IL-2 and IFN- $\gamma$, whereby IFN- $\gamma$ levels decreased in the control group that consumed less seafood. There were also slight tendencies for IL-6 levels to decrease (and S100B levels to increase) with more reading together in ADHD families and to show the opposite with less time together in control families.

\section{Discussion}

"There is now a compelling case that the early environment is specifically linked with impaired cognitive function, behavioural disorders especially hyperactivity/inattention ..." (Schlotz and Phillips 2009). We showed earlier that there are associations between metabolites of the tryptophan/kynurenine pathway and cytokine activity with the symptoms and the attention-related performance of children with ADHD (Oades et al. 2010a, b). This report 
explores with a regression analysis whether the toxic and protective products of tryptophan/kynurenine metabolism, that largely occurs in glial cells (Kiss et al. 2003), and the cytokines that modulate the metabolic route relate statistically to some of the early potentially adverse environmental experiences of the foetus and infant. Such associations could potentially provide indications of the source of an influence in pregnancy that could contribute to the aetiology of some of the anomalous components of the ADHD phenotype.

The preliminary findings are presented and discussed in 4 clusters (the birth, smoking and alcohol use, pregnancy features and child care: tables 4-7) and finally in terms of the metabolites and cytokines separately, as follows.

1: birth) A shorter pregnancy and a smaller birth weight (without extreme values) for children who later developed ADHD was associated with increasing levels of the potentially neurotoxic $3 \mathrm{HK}^{1}$, the pro-inflammatory cytokines IFN- $\gamma$ and particularly with decreasing levels of TNF$\alpha$. The relationship with TNF- $\alpha$ extended to obstetric problems at birth. (Both of these cytokines belong to the Th1 immune response system.)

There are numerous epidemiological reports of an association between low birth weight after a short gestation and the later development ADHD symptoms (O'Callaghan et al., 1996) or indeed a diagnosis of ADHD for at least 1 in 6 cases (Mick et al. 2002; Whitaker et al. 1997). However, there have been negative

\footnotetext{
1 The potential toxicity may result from the agonism of the $3 \mathrm{HK}$ metabolite quinolinic acid at NMDA receptors (Ribeiro et al. 2006). But, it may be noted that further metabolism to $\mathrm{NAD}(+)$ could in theory facilitate energy metabolism (Costantino 2009). The putative toxic or protective metabolic route is controlled by the indoleamine and tryptophan 2,3,-dioxygenases whose activity is modulated by the balance of pro-/anti-inflammatory cytokines (Myint et al. 2007).
}

findings that lead Gustafsson and Källen (2010) to emphasize that these features constitute a weak risk factor. Nonetheless, the present results are of interest as they do not include extreme values typical of the epidemiological reports.

The few studies that relate to our biochemical findings (and are not primarily concerned with the challenge of infection or overt pathology) used animals. First, activity of the enzyme kynureninase, active in 3HK metabolism, is attenuated in pregnancy and by reduced availability of vitamin B6 (van de Kamp and Smolen 1995). Thus, the state of the mother makes an anomaly in kynurenine metabolism in the offspring plausible, where, in the present case, ADHD is an eventual outcome.

Secondly, a decrease of proinflammatory cytokines can follow hypoxia in newborn rats (Ashdown et al. 2008). This is consistent with decreasing TNF- $\alpha$ with birth problems and a trend for decreasing IFN- $\nu$ with poor APGAR indices of oxygenation in the present study. However, a study of the complication of allergy in 12 year-olds reported no difference in the cytokine profile following term and preterm birth (Mai et al. 2003). Clearly more studies of the biochemical responses of offspring with different outcomes would be helpful.

2: Smoking) Maternal smoking during pregnancy related to decreasing kynurenine and increasing $3 \mathrm{HK}$ and S100B levels in ADHD children, while paternal smoking related to increasing tryptophan levels in the controls and increasing IL-6 levels in ADHD children. There was a moderate consistency for both sets of measures before, during and after the pregnancy establishing the long-term nature of the habit and its consequences.

Studies relating parental smoking to kynurenine metabolism in the offspring have not yet been published. However, as 
$\mathrm{KA}$ is an antagonist of $\alpha 7$ nicotinic cholinergic binding sites (Zmarowski et al. 2009) and considering the nicotine/cholinergic effects of smoking, an influence on kynurenine metabolism might have been expected. But the present results suggest that this cholinergic aspect was not pertinent for ADHD families. Instead there are modest signs of increasingly toxic metabolism in the ADHD offspring with increasing levels of 3HK (Connor et al. 2008, dioxygenase induction after inflammatory challenge), S100B (Himeda et al. 2006 with MPTPtreated mice)) and the pro-inflammatory IL-6 (Harding et al. 2005 on premature children).

There is a surprising divergence of claims about the cytokine status of smokers. Levels of all cytokines in pregnant women (Tsunoda et al. 2003) or, generalizing, at least the inflammatory cytokines (Zhang et al. 2008) may be suppressed in smokers. Yet, others found the responses of pro- and antiinflammatory examples to be increased in smokers (e.g., IL-6, TNF- $\alpha$, IL13: Noakes et al. 2003; Tappia et al. 1995). The one report on the responsiveness in neonatal offspring of smokers and nonsmokers found no differences for the Th1 cytokines (Noakes et al. 2003).

The present data indicate separate associations for S100B (maternal smoking) and IL-6 (paternal smoking). Considering some similarity in the nature of the exposure, this suggests that there is a quite separate intervening or mediating variable that may relate to the state or personality traits of the parents who smoked. This idea is supported by studies using assisted reproductive technology. They showed that the ADHD condition depended on inherited features from the conceiving mother rather than being dependent on the smoking status of the mother bearing the child (Thapar et al. 2009; Rice et al. 2010). One might speculate from the current data that a feature of the child's serotonin metabolism may be mediating the response to their "type" of parent. S100B (levels related to maternal smoking) is involved in the neurotrophic functions of serotonin (Azmitia 2001), and the build up of tryptophan (paternal smoking) would likely result in reduced metabolism in the serotonin pathway.

3: Pregnancy) For the ADHD families the significant regression suggests that an effect of the taking of supplements at various stages of the pregnancy was passed on as an induced antiinflammatory response. This consisted of decreasing TNF- $\alpha$ (proinflammatory), and increasing IL-10 levels (antiinflammatory), that were associated with supplement use in trimesters 1 and 3 . In addition decreasing 5-HIAA levels in the children related to the use of supplements in T2. But, stressful life events (T1), while not clearly related to cytokine levels, were associated with less 5-HIAA. Maternal complications and late T3 life events tended to be reflected by a build up of tryptophan and $K A$, respectively. But, on the whole, maternal illness or other pregnancy-related complications were unrelated to metabolite and cytokine levels in ADHD children.

Maternal pregnancy-related complications and neonatal problems have frequently been reported to constitute risk factors for the development of ADHD (Amor et al. 2005; Biederman 2005). However, the present small sample of ADHD families here showed no convincing relationships with levels of tryptophan metabolites or cytokines in the offspring (table 6). Indeed, the control families reported maternal complications more frequently (table 3 ). It is also worth noting that the incidence of illness in the pregnant mother was unrelated to an ADHD outcome in the offspring. This contrasts with severe psychiatric 
outcomes of infection such as psychosis (King et al. 2010) and increases of proinflammatory cytokines in young rodents at 6 months following maternal exposure to toxins during the pregnancy (Romero et al. 2007).

Stress, particularly in the form of lifeevents during pregnancy, can have a negative effect on the cognitive and emotional characteristics of the offspring (Bergman et al. 2007; Grizenko et al. 2008; review Talge et al. 2007). Indeed, multiple regression analysis showed a significant association between maternal stressful events and ADHD behaviour (Ronald et al. 2011). Such life events are reflected by changes in the maternal levels of pro- and anti-inflammatory cytokines (Entringer et al. 2008). Thus, it is surprising that no convincing associations with the cytokines were observed in the present study. Nonetheless, decreased serotonergic metabolism along with an increase of KA levels in the ADHD children could be interpreted as a warning signal and a neuroprotective response.

The sensitivity of the levels of cytokines and metabolites in the children to the maternal use of supplements is initially surprising. However, research does suggest that maternal anxiety can be moderated by diet (Talge et al. 2007), and that the gestational status of micronutrients (e.g. iron and folate) can have long term consequences for cognitive and behavioural problems (Schlotz and Phillips 2009). The argument is that the perceived need for supplements and/or the consequence of taking supplements reflects raised levels of maternal anxiety. Maternal anxiety during pregnancy has been reported to account for as much as $22 \%$ of the variance in ADHD symptoms shown by 8 $9 y$-old children (Van den Bergh and Marcoen 2004). On the question of whether the current data are suggestive of an especially sensitive period ("the Barker hypothesis": Godfrey and Barker 2001), one may note the modest emphasis on significant data relating to either early (T1) or late (T3) stages in the pregnancy

4: Child care) In the postnatal period, in the absence of meaningful data on suckling and features of infant health, some diet and socio-familial features were considered. Surprisingly, in contrast to infant health, child care (seafood consumption and time-together) was rated descriptively higher in ADHD than control families. While poorer infant health was associated with increased IL-16 and 5-HIAA levels in the ADHD group, increased child care was related to lower tryptophan levels and alterations in the balance of pro-inflammatory cytokines, (increases of IL-2, IFN- $\psi$, S100B and decreases of (L-6). These were very modest, yet consistent trends. The positive influence of child care should not be underestimated. Recently it was well shown how the negative effect of prenatal cigarette-exposure on the development of executive attention in the offspring was countered by the positive effect of parenting practices (infant learning stimulation: Mezzacappa et al. 2011). Across measures control families showed associations that were either nonsignificant or the opposite to those of the ADHD group.

Adverse events early in life profoundly affect brain development and later behaviour, and may contribute to the occurrence of psychiatric disorders (Niwa et al. 2011). In our sample infant health was not especially poor; however, the association with increased serotonin metabolism would suggest a relationship to the potential development of cognitive impulsivity (Oades et al. 2002) and with increased IL-16 might point to a contribution to increased allergy sensitivities (Oades et al. 2010a).

\section{Tryptophan metabolism}


Most trends in the regression analyses of metabolite and cytokine data (87\%) pertain to the ADHD families. Generalising from the metabolite data, a build-up of tryptophan and reduced 5-HIAA levels (reduced serotonin metabolism) in ADHD children reflected that the mother had experienced more complications, more life-events and taken more supplements during the pregnancy. This is consistent with maternal anxiety leading to increased behavioural impulsivity in these children (Oades et al. 2002; 2010b). The interpretation is also consistent with animal models, where, for example, adverse experience of the mother can be associated with adult problems in the offspring in mice associated with frontoamygdaloid metabolism (Niwa et al. 2011).

Curiously increased tryptophan levels were also seen in healthy families where the father smoked. In contrast, in ADHD families maternal smoking related to decreasing kynurenine and increasing $3 \mathrm{HK}$ in the children. Increasing $3 \mathrm{HK}$ levels were also associated with a shorter pregnancy, lower birth weight and APGAR levels. As, at the time of sampling, levels of the potentially toxic $3 \mathrm{HK}$ were on average lower in children with ADHD than in controls, any trend towards an increase may be viewed as a risk factor for the later development of the CNS through adolescence, as shown in several species of mammal (Cerresoli-Borroni et al. 2007).

\section{Cytokine levels}

Increasing S100B levels were associated with some risk factors for a disorder (e.g. shorter pregnancy, smaller birthweight, maternal smoking). Within limits this could be regarded as a protective response. In brain slices S100B activates the NFKB signalling cascade essential for the development of neural pathways and neurites (Villarreal et al. 2011). However much higher levels of S100B have a negative impact and are associated with other major psychiatric disorders such as schizophrenia (Zhang et al. 2008)

Regression analysis showed that increasing levels of anti-inflammatory cytokines may have resulted from several potential problems (e.g. IL-10, -13, -16 in supplement use, maternal smoking, alcohol consumption and obstetric difficulties). This paralleled decreasing levels of pro-inflammatory cytokines associated with the length of gestation, supplement use, birth difficulties (TNF- $\alpha$ ), and shorter pregnancy (IL-6). However, while increased S100B and IFN- $\gamma$ levels were partially explained by maternal smoking and drinking, decreasing IL-6 levels related to paternal smoking. Curiously these changes in cytokine levels also tended to reflect desirable trends in child care. It is notable that there were several cases (S100B, IFN- $\gamma$, IL-16) where the regression result in controls was opposite to that found in ADHD families. This supports the interpretation of the biochemical data in terms of markers of the effect of an underlying process separating healthy and ADHD children, rather than representing indicators of direct causal relationships with events or symptoms.

\section{Limitations:}

In this preliminary study the number of subjects in each group was far too small for giving unequivocal results about the relationships between biochemical markers in the offspring and problems experienced earlier in utero. Considering, for example the metabolite measures in the 35 cases of ADHD, to achieve $\alpha=5 \%$ the power improved from 0.4 for a relatively small effect size $\left(R^{2}=0.15\right)$ to a satisfactory level of $\geq 0.8$ with $R^{2} \geq 0.30$ (based on Cohen's $f^{2}$ statistic). The power was less in the smaller subject groups. However, the numbers recruited here are in line with those studied in other recent exploratory reports of these metabolites and cytokines in young psychiatric groups ( $N=28-34$ patients: Barry et al. 2009; 
Condray et al. 2011; Gabbay et al. 2009; Olson et al. 2010; Suzuki et al. 2011). An increase in the future would incur a valuable increase in statistical power and reduce the influence of outliers evident in some of the present analyses. But the aim was to provide an initial exploration of whether there were any indications that glial metabolites and psychoimmunological features of children with ADHD could possibly reflect in part their earlier environment and experience as a foetus. The advantage of restricting the study group to children with a strict diagnosis of ADHD-combined type also incurs a constraint on interpreting any of the results in terms of contributions from the inattentive or hyperactive-impulsive subgroups. Inevitably much of the data were semi-quantitative and relied on retrospective ratings by the mother. This also means that the degree to which one effect was shown cannot be directly compared with a second. Nonetheless, by removing effects driven by extreme values, more trends and significant associations were demonstrated than could be explained by chance.

\section{Conclusions and future work:}

Future studies should, if possible, be made prospectively, use more than one time point for sample collection and recruit many more subjects. Having demonstrated associations of glial metabolism of tryptophan and kynurenine with a number of perinatal experiences future studies should extend analysis to other potentially toxic metabolites (e.g. quinolinate) and energy sources (NAD). As the data indicate that some pro- and antiinflammatory responses were significantly associated with pre- and postnatal features future research should extend analyses to other members of these cytokine families (e.g. IL-1b, IL-4, and IL17). Also meriting attention is the NFKB signalling pathway that can activate cytokine expression and is regulated by
S100B (Villarreal et al. 2011). A prospective study focused on the balance of pro- and anti-inflammatory cytokines along with a selection of mothers who had experienced, preterm birth, infection or intra-uterine growth restriction would contribute greatly to understanding the factors that influence risk for mental disability and ADHD (Deverman and Patterson 2009). Lastly, in view of the increasing validation of the juvenile spontaneously hypertensive rat as a model for ADHD (Sagvolden et al. 2005), there is the potential for teasing out the potential pathophysiological pathways with markers that are available to in vitro as well as in vivo study. In conclusion, the present exploration has already indicated that tryptophan metabolism and the cytokines may moderate the expression of symptoms and attention-related function in ADHD (Oades et al. 2010a, b): the current analysis proposes that the early perinatal environment may have influenced this development.

\section{Abbreviations}

ADHD, Attention-deficit/hyperactivity disorder; DSM-IV, Diagnostic and Statistical Manual of the American Psychiatric Association, $4^{\text {th }}$ edition; $\mathrm{HI}$, hyperactive-impulsive; 5-HIAA, 5-hydroxyindoleacetic acid; IA, inattentive; IL, Interleukin; IFN- $\gamma$, Interferon gamma; KA, kynurenic acid; 3HK, 3-hydroxykynurenine; NAD, Nicotinamide adenine dinucleotide; NFKB, Nuclear factor kappalight-chain-enhancer of activated B cells; SES, Socio-economic scale; SD, Standard Deviation; TNF- $\alpha$, Tumour necrosis factor alpha;

\section{Acknowledgments}

I am very grateful to Benno Schimmelmann, Maria Dauvermann, Victoria Kirchhoff, Adriana Banozic and Ellen Uslar for their help in running this study in Essen, and to Aye-Mu Myint, Markus Schwarz and Johana Zach for their 
role in organizing and running the biochemical analyses in Munich. We thank UCB Pharma GmbH for financial support.

\section{Competing interests}

RDO declares that he has no conflicting

\section{Reference List}

Amor LB, Grizenko N, Schwartz G et al (2005) Perinatal complications in children with attention deficit hyperactivity disorder and their unaffected siblings. J Psychiat Neurosci 30: $120-126$

Ashdown $\mathrm{H}$, Joita $\mathrm{S}$, Luheshi $\mathrm{GN}$ et al (2008) Acute brain cytokine responses after global birth hypoxia in the rat. J Neurosci Res 86: 3401-3409

Azmitia EC (2001) Modern views on an ancient chemical: serotonin effects on cell proliferation, maturation, and apoptosis. Brain Res Bull 56: 413-424

Barkley RA, DuPaul GJ, McMurray MB (1990) Comprehensive evaluation of attention deficit disorder with and without hyperactivity as defined by research criteria. J Consult Clin Psychol 58: 775-789

Barry S, Clarke G, Scully P et al (2009) Kynurenine pathway in psychosis: evidence of increased tryptophan degradation. J Psychopharmacol 23: 287-294

Bergman K, Sarkar P, O'Connor TG et al (2007) Maternal Stress During Pregnancy Predicts Cognitive Ability and Fearfulness in Infancy. J Am Acad Child Adolesc Psychiat 46: 1454-1463

Biederman J (2005) AttentionDeficit/Hyperactivity Disorder: A Selective Overview. Biol Psychiatry 57: 1215-1220

Blank R, Remschmidt H (1994) Hyperkinetic syndrome: the role of allergy among psychological and neurological factors. Eur Child Adolesc Psychiatry 3: 220-228 interests. Some of these data were communicated at the $10^{\text {th }}$ Psychoimmunology Expert meeting at Ulm/Günzburg, 12-14 ${ }^{\text {th }}$ Nov. 2009 (Oades et al. 2009).

Bock J, Braun K (2011) The impact of perinatal stress on the functional maturation of prefronto-cortical synaptic circuits: Implications for the pathophysiology of ADHD? Prog Brain Res 189: 155-169

Boksa P (2010) Effects of prenatal infection on brain development and behavior: A review of findings from animal models. Brain Behav Imm 24: 881-887

Bourgeois JP, Rakic P (1993) Changes of synaptic density in the primary visual cortex of the macaque monkey from fetal to adult stage. J Neurosci 13: 2801-2820

Brauns H, Haun D, Steinmann S (1997) The construction of an internationally comparable classification by class. Erwerbsstatistische Besonderheiten am Beispiel von Labour Force Surveys der Bundesrepublik Deutschland, Frankreichs, Großbritanniens und Ungarns. Mannheim, Germany

Castellanos FX, Tannock R (2002) Neuroscience of attentiondeficit/hyperactivity disorder: the search for endophenotypes. Nat Rev Neurosci 3: 617-628

Cerresoli-Borroni G, Guidetti P, Amori L et al (2007) Perinatal kynurenine 3hydroxylase inhibition in rodents: Pathophysiological implications. J Neurosci Res 85: 845-854

Chen W, Asherson P, Taylor EA (2005) Gene-Environment Interaction Questionnaire. Kings College, University of London

Chen W, Taylor EA (2006) Parental Account of Children's Symptoms (PACS), ADHD phenotypes and its 
application to molecular genetic studies. In: Oades RD (ed) AttentionDeficit/Hyperactivity Disorder and the Hyperkinetic Syndrome: Current Ideas and Ways Forward. Nova Science Publishing Inc., Hauppauge, NY 11788, pp 3-20

Condray R, Dougherty GG, Keshavan MS et al (2011) 3-Hydroxykynurenine and clinical symptoms in first-episode neuroleptic-naive patients with schizophrenia. Int J Neuropsychopharmacol 14:756-767

Conners CK (2002) Manual for Conners' rating scales. Revised edn. Multi-Health Systems Inc., N.Tonoawanda, NY

Connor TJ, Starr N, O'Sullivan JB, et al (2008) Induction of indoleamine 2,3dioxygenase and kynurenine 3monooxygenase in rat brain following a systemic inflammatory challenge: $A$ role for IFN-?? Neurosci Lett 441: 29-34

Costantino $G$ (2009) New promises for manipulation of kynurenine pathway in cancer and neurological diseases. Expert Opin Ther Targets 13: 247-258

Das Banerjee T, Middleton F, Faraone SV (2007) Environmental risk factors for attention-deficit hyperactivity disorder. Acta Paediatr 96: 1269-1274

Deverman BE, Patterson PH (2009) Cytokines and CNS Development. Neuron 64: 61-78

Djuardi Y, Wibowo H, Supali T et al (2009) Determinants of the Relationship between Cytokine Production in Pregnant Women and Their Infants. PLOS ONE 4: e7711

Entringer S, Kumsta R, Nelson EL et al (2008) Influence of prenatal psychosocial stress on cytokine production in adult women. Dev Psychobiol 50: 579-587

Fatemi SH, Sidwel R, Kist D et al (1998) Differential expression of synaptosomeassociated protein $25 \mathrm{kDa}$ [SNAP-25] in hippocampi of neonatal mice following exposure to human influenza virus in utero. Brain Res 800: 1-9

Gabbay V, Coffey BJ, Guttman LE et al (2009) A cytokine study in children and adolescents with Tourette's disorder. Prog Neuropsychopharm-acol Biol Psychiatry 33: 967-971

Gallagher CN, Carpenter KLH, Grice P et al (2009) The human brain utilizes lactate via the tricarboxylic acid cycle: a 13Clabelled microdialysis and highresolution nuclear magnetic resonance study. Brain 132: 2839-2849

Godfrey KM, Barker DJ (2001) Fetal programming and adult health. Public Health Nutr 4: 611-624

Graciarena M, Depino AM, Pitossi FJ (2010) Prenatal inflammation impairs adult neurogenesis and memory related behavior through persistent hippocampal TGF? 1 down-regulation Brain Behav Imm 24: 1301-1309

Grizenko N, Shayan YR, Polotskaia A et al (2008) Relation of maternal stress during pregnancy to symptom severity and response to treatment in children with ADHD. J Psychiat Neurosci 33: 1016

Gustafsson P, Källen K (2010) Perinatal, maternal, and fetal characteristics of children diagnosed with attentiondeficit-hyperactivity disorder: results from a population-based study utilizing the Swedish Medical Birth Register. Dev Med Child Neurol 53: 269-274

Harding D, Brull D, Humphries SE, et al (2005) Variation in the interleukin-6 gene is associated with impaired cognitive development in children born prematurely: a preliminary study Pediatr Res 58:117-120

Himeda $T$, Watanabe $Y$, Tounai $H$, et al (2006) Time dependent alterations of co-localization of S100ß and GFAP in the MPTP-treated mice. J Neural Transm 113: 1887-1894

Holtze M, Asp L, Schwieler L, et al (2008) Induction of the kynurenine pathway 
by neurotropic influenza a virus infection. J Neurosci Res 86: 3674-3683

Hsiao EY, Patterson PH (2011) Activation of the maternal immune system induces endocrine changes in the placenta via IL-6 Brain Behav Imm 25: 604-615

Huttenlocher PR (1984) Synapse elimination and plasticity in developing human cerebral cortex. Am J Ment Defic Res 88: 488-496

Kaufman AS, Kaufman NL (2001) KaufmanAssessment Battery for Children. 5th edition, transl. P. Melchers, U. Preuß edn. Swets \& Zeitlinger, Frankfurt am Main, Germany,

King S, St-Hilaire A, Heidkamp D (2010) Prenatal Factors in Schizophrenia. Current Directions in Psychological Science 19: 209

Kiss C, Ceresoli-Borroni G, Guidetti P et al (2003) Kynurenate production by cultured human astrocytes. J Neural Transm 110: 1-14

Klein $C$, Wendling $K$, Huettner $P$ et al (2006) Intra-subject variability in attention-deficit hyperactivity disorder (ADHD). Biol Psychiatry 60: 1088-1097

Knopik VS, Sparrow EP, Madden PAF (2005) Contributions of parental alcoholism, prenatal substance exposure, and genetic transmission to child ADHD risk: a female twin study. Psychol Med 35: 625-635

Knopik VS, Heath AC, Buchholz KK et al (2009) Genetic and environmental influences on externalizing behavior and alcohol problems in adolescence: $A$ female twin study. Pharmacol Biochem Behav 93: 313-321

Kuntsi J, Andreou P, Ma J et al (2005) Testing assumptions for endophenotype studies in ADHD: Reliability and validity of tasks in a general population sample. BMC Psychiatry 5: 40

Lasky-Su J, Neale BM, Franke B et al (2008) Genome-wide association scan of quantitative traits for Attention Deficit
Hyperactivity Disorder identifies novel associations and confirms candidate gene associations. Am J Med Genet Part B 147B: 1345-1354

Lodygensky GA, Seghier ML, Warfield SK et al (2008) Intrauterine growth restriction affects the preterm infant's hippocampus. Pediatr Res 63: 438-443

Mai XM, Gäddin PO, Nilsson L et al (2003) Asthma, lung function and allergy in 12year-old children with very low birth weight: a prospective study. Pediatr Allergy Immunol 14: 184-192

McClelland S, Korosi A, Cope J et al (2011) Emerging roles of epigenetic mechanisms in the enduring effects of early-life stress and experience on learning and memory. Neurobiol Learn Mem 96: 79-88

Mezzacappa E, Buckner JC, Earls F (2011) Prenatal cigarette exposure and infant learning stimulation as predictors of cognitive control in childhood. Dev Sci 14: 881-891

Mick E, Biederman J, Prince J et al (2002) Impact of low birth weight on attention-deficit hyperactivity disorder. J Dev Behav Pediatr 23: 16-22

Müller UC, Asherson P, Banaschewski T et al (2011) Behavioural patterns of ADHD in a large multicentre study. Part 1: Demographics, diagnoses, and symptoms in probands and selected siblings of the IMAGE project. BMC Psychiatry in submission:

Myint AM, Kim YK, Verkerk R et al (2007) Kynurenine pathway in major depression: Evidence of impaired neuroprotection. J Affect Disord 98: 143-151

Nagy Z, Lagercrantz H, Hutton C (2011) Effects of Preterm Birth on Cortical Thickness Measured in Adolescence. Cereb Cortex 21: 300-306

Niwa $M$, Matsumoto $Y$, Mouri $A$ et al (2011) Vulnerability in early life to changes in the rearing environment plays a crucial role in the 
aetiopathology of psychiatric disorders. Int J Neuropsychopharmacol DOI: 10.1017/S1461145710001239

Noakes PS, Holt PG, Prescott SL (2003) Maternal smoking in pregnancy alters neonatal cytokine responses. Allergy 58: 1053-1058

O'Callaghan MJ, Burns YR, Gray PH et al (1996) School performance of ELBW children: a controlled study. Dev Med Child Neurol 38: 917-926

O'Donnell K, O'Connor TG, Glover V (2009) Prenatal Stress and Neurodevelopment of the Child: Focus on the HPA Axis and Role of the Placenta. Dev Neurosci 31: 285-292

Oades RD, Dauvermann MR, Schimmelmann BG et al (2010a) Attention-deficit hyperactivity disorder (ADHD) and glial integrity: S100B, cytokines and kynurenine metabolism effects of medication. Behav Brain Funct 6: 29

Oades RD, Dauvermann MR, Schwarz MJ et al (2009) Does glial function underlie ADHD variability? Evidence from measures of S100B, interleukins, tryptophan metabolism and the kynurenine metabolic pathway. Neurol Psychiat Brain Res Supplement 1: 44

Oades RD, Myint AM, Dauvermann MR et al (2010b) Attention-deficit hyperactivity disorder (ADHD) and glial integrity: an exploration of associations of cytokines and kynurenine metabolites with symptoms and attention Behav Brain Funct 6: 32

Oades RD, Slusarek $M$, Velling $S$ et al (2002) Serotonin platelet-transporter measures in childhood attentiondeficit/hyperactivity disorder (ADHD): clinical versus experimental measures of impulsivity. World J Biol Psychiatry 3: 96-100

Olsson SK Samuelsson M, Saetre $P$ et al (2010) Elevated levels of kynurenic acid in the cerebrospinal fluid of patients with bipolar disorder. J Psychiatry Neurosci 39: 195-199

Polanczyk GV, Silva de Lima M, Horta BL et al (2007) The Worldwide Prevalence of ADHD: A Systematic Review and Metaregression Analysis. Am J Psychiatry 164: 942-948

Ribeiro CAJ, Grando V, Filho CSD et al (2006) Evidence that quinolinic acid severely impairs energy metabolism through activation of NMDA receptors in striatum from developing rats. J Neurochem 99: 1531-1542

Rice F, Harold GT, Boivin J et al (2010) The links between prenatal stress and offspring development and psychopathology: disentangling environmental and inherited influences. Psychol Med 40: 335-345

Romanos M, Gerlach M, Warnke A et al (2010) Association of attentiondeficit/hyperactivity disorder and atopic eczema modified by sleep disturbance in a large population-based sample. J Epidemiol Commun Health 64: 269-273

Romero E, Ali C, Molina-Holgado E et al (2007) Neurobehavioral and Immunological Consequences of Prenatal Immune Activation in Rats. Influence of Antipsychotics. Neuropsychopharmacol 32:1791-1804

Ronald A, Pennell CE, Whitehouse AJ (2011) Prenatal maternal stress associated with ADHD and autistic traits in early childhood. Front Psychology 1: 223 doi: 10.3389/ fpsyg.2010.00223

Russell VA, Oades RD, Tannock $R$ et al (2006) Response variability in attention-deficit/hyperactivity disorder: a neuronal and glial energetics hypothesis. Behav Brain Funct 2: 30

Sagvolden $T$, Johansen EB, Aase $H$, et al (2005) A dynamic developmental theory of attention-deficit/ hyperactivity disorder (ADHD) predominantly 
hyperactive/impulsive and combined subtypes. Behav Brain Sci 28: 397-468

Schlotz W, Phillips DW (2009) Fetal origins of mental health: Evidence and mechanisms. Brain Behav Imm 23: 905916

Shaw P, Eckstrand K, Sharp W et al (2007) Attention-deficit/hyperactivity disorder is characterized by a delay in cortical maturation. Proc Natl Acad Sci (USA) 104: 19649-19654

Steiner J, Bernstein $\mathrm{H}-\mathrm{G}$, Bielau $\mathrm{H}$ et al (2007) Evidence for a wide extraastrocytic distribution of $\mathrm{S} 100 \mathrm{~B}$ in human brain. BMC Neurosci 8: 2

Stöber G, Ben-Shachar D, Cardon $M$ et al (2009) Schizophrenia: From the brain to peripheral markers. A consensus paper of the WFSBP task force on biological markers. World J Biol Psychiatry 10: 127-155

Suzuki,K.; Matsuzaki,H.; Iwata,K. et al (2011) Plasma Cytokine Profiles in Subjects with High-Functioning Autism Spectrum Disorders. PLoS ONE 6: 5

Talge NM, Neal C, Glover $V$ et al (2007) Antenatal maternal stress and longterm effects on child neurodevelopment: how and why? J Child Psychol Psychiatry 48: 245-261

Tappia PS, Troughton KL, Langley-Evans SC et al (1995) Cigarette smoking influences cytokine production and antioxidant defences. Clin Sci (Lond) 88: 485-489

Taylor EA, Sandberg S, Thorley $G$ et al (1991) The epidemiology of childhood hyperactivity. Oxford University Press, Oxford, UK,

Thapar A, Rice F, Hay D et al (2009) Prenatal Smoking Might Not Cause Attention-Deficit/Hyperactivity

Disorder: Evidence from a Novel Design. Biol Psychiatry 66: 722-727

Tsunoda M, Litonjua AA, Kuniak MP et al (2003) Serum cytokine levels, cigarette smoking and airway responsiveness among pregnant women. Int Arch Allergy Immunol 130: 158-164

Uebel $H$, Albrecht $B$, Asherson $P$ et al (2010) Performance variability, impulsivity errors and the impact of incentives as gender-independent endophenotypes for ADHD. J Child Psychol Psychiatry 51: 210-218

van de Kamp JL, Smolen A (1995) Response of kynurenine pathway enzymes to pregnancy and dietary level of vitamin B-6. Pharmacol Biochem Behav 51: 753-758

Van den Bergh BRH, Marcoen A (2004) High Antenatal Maternal Anxiety Is Related to ADHD Symptoms, Externalizing Problems, and Anxiety in 8- and 9-Year-Olds. Child Dev 75: 10851097

Villarreal A, Aviles Reyes RX, Angelo MF, et al (2011) S100B alters neuronal survival and dendrite extension via RAGEmediated NF-kB signalling. J Neurochem 117: 321-332

Whitaker AH, Van Rossem R, Feldman JF et al (1997) Psychiatric outcomes in low-birth-weight children at age 6 years: relation to neonatal cranial ultrasound abnormalities. Arch Gen Psychiatry 54: 847-856

Winter C, Reutiman TJ, Folsom TD et al (2008) Dopamine and serotonin levels following prenatal viral infection in mouse-Implications for psychiatric disorders such as schizophrenia and autism. Eur Neuropsychopharmacol 18: 712-716

Zhang XY, Cao LY, Song C et al (2008) Lower serum cytokine levels in smokers than non-smokers with chronic schizophrenia on long-term treatment with antipsychotics. Psychopharmacol 201: 383-389

Zmarowski A, Wu H-Q, Brooks JM et al (2009) Astrocyte-derived kynurenic acid modulates basal and evoked cortical acetylcholine release. Eur J Neurosci 29: 529-538 
